\title{
Changing the subject in teacher education: Centering Indigenous, diasporic, and settler colonial relations
}

\author{
Martin J. Cannon, PhD \\ OISE/University of Toronto \\ martin.cannon@utoronto.ca
}

\begin{abstract}
This paper suggests that, so long as we are focused on racism and colonialism as an exclusively Indigenous struggle, we fail to engage non-Indigenous peoples as "allies" of Indigenous education and sovereignty. My goal is to place a developing literature on settler-Indigenous alliances into a productive and more explicit dialogue with anti-oppressive educational theory and praxis. I address two critical questions: 1) How might we engage structurally privileged learners, some of whom are non-Indigenous peoples, to think about colonial dominance and racism in Canada? and 2) How might we work in coalition with privileged learners - and especially with new Canadians - to consider matters of land, citizenship, and colonization? I conclude by identifying a series of pedagogical practices aimed at the troubling of normalcy —an approach to teaching that disrupts the binary of self/Other. I consider briefly in turn the implications of this pedagogy for decolonization, the invigoration of teacher education programs in Canada, and the building and rejuvenation of relationships between Indigenous peoples and settler, diasporic, and migrant Indigenous populations.
\end{abstract}

\section{Introduction}

For over a decade, I have been engaging with people - the majority, non-Indigenous - in the shared challenge of thinking about histories of racism, racialization, and colonialism. One obstacle in doing this work involves upsetting people's investment in seeing Canada as a fair, generous, and tolerant nation. A far greater challenge comes with asking white settler and diasporic peoples to consider and transform their own investment in and relationship with colonialism.

In Canada, it is routine to think about colonialism as having little, if anything, to do with non-Indigenous peoples. As such, it is typically Indigenous scholars, teachers, and populations who are left to explain the impact of colonization and residential schooling on our communities, and the history of oppressive legislation. As hooks observed, in analysis specific to the United States and Afro-Americans, "where [black] people are called upon to take primary responsibility for sharing experiences, ideas, and information [they are placed] once again in a service position, meeting the needs of whites" (1988, p. 47). While distinctions must be drawn between Indigenous peoples and ethnic/racial groups - in light of our history and sovereignty as nations (Cannon \& Sunseri, 2011; Porter, 1999)_I believe hooks' message has as much currency within Indigenous contexts.

My intention is not to impart that the space we, as Indigenous peoples, have fought for in order to explain the impact of colonization on our lives is unimportant, nor that we should abandon it altogether. Instead, I propose that as long as we remain focused on racism and colonialism as an exclusively Indigenous struggle, we do very little in the way of encouraging 
non-Indigenous peoples to think about what it might mean to be an "ally" of Indigenous sovereignty and education. Moreover, we do little to urge them to think about matters of restitution, their own decolonization, and transforming their complicity in ongoing dispossession.

Others have raised the matter of having non-Indigenous peoples think carefully about their relationship with settler colonialism in Canada. Ukwehuwe - used in some of our communities to refer to "the people"-have voiced this idea in a myriad of contexts. On 28 September 2010, the Honourable Justice Murray Sinclair, Chair of Canada's Truth and Reconciliation Commission (TRC), appeared before the Senate to update them on the TRC's progress since the 2008 Parliamentary apology (Government of Canada, 2010). He insisted:

The residential schools have had such a dramatic impact upon Aboriginal people in Canada that sometimes people believe it is an Aboriginal problem. It is not an Aboriginal problem. It is a problem that all people in Canada need to think about and address. (p. 7-8) It is incumbent upon us to take Justice Sinclair's assertion seriously. If the history of colonization is a problem facing all Canadians, then it is each and every Canadian who needs to acknowledge and understand how this is so. Canadians must come to know and understand the privilege of not having to know, name, or otherwise mark their own subjectivity and positionality relative to the ongoing project of settler colonialism. Indeed, I am suggesting that we need a wholesale rethinking of our departure points in educational, methodological, and activist-based contexts. We need to think of frameworks that start — not with Indigenous peoples — but with the identity-making processes, many of them racialized, that are specific to colonization and nonIndigenous Canadians.

What might these frameworks look like in practice? In developing possibilities, five preliminary questions come to mind, given my life as a Haudenosaunee person and my experience as a scholar:

1. Who do Canadian citizens know themselves to be, and how much of who they think they are depends on keeping racialized others, status Indians in particular, firmly in place?

2. How do we explain the need for certainty about Indigenous difference, and how much of this is tied to the dispossession of lands?

3. What are modern-day practices of difference- making, where are they located, and how do they operate in the contemporary world?

4. How do non-Indigenous peoples interact with our difference and alterity?

5. What sorts of material and symbolic work have gone into the dispossession of lands and spaces, including the urban spaces we occupy and have always occupied?

These questions do not exhaust the theoretical range of possibilities in thinking about colonialism from an entirely different point of departure. However, contemplating each of them would serve to illuminate more explicitly the ongoing nature of colonialism.

The refusal, or perhaps inability, to mark and name this history continues to be one of the most formidable challenges facing settler-Indigenous collaborations into the twenty-first century (see Dion, 2009; Morgensen, 2011; Thobani, 2007). However, established literature has addressed this challenge, as well as the issue of alliance building (see Davis, 2010; Lawrence \& Amadahy, 2009; Mathur et al., 2011; Miles \& Holland, 2006; Regan, 2010). In a more in-depth discussion, I will later explore a decolonizing framework specific to the Canadian colonial situation - centered on privileged learners (often non-Indigenous peoples) and the rejuvenation and realization of settler-Indigenous alliances.

Several Indigenous scholars have written about the matter of encouraging non-Indigenous peoples to contemplate settler colonialism (see Alfred, 2010; Dion, 2009; St. Denis, 2009; St. 
Denis \& Schick, 2003; Unsettling Minnesota Collective, 2009). Their words bring to mind the story of a Kanienkehaka man who, when asked to recount his residential school experience for an Indian Affairs publication in 1965, responded astutely: “... when I was asked to do this paper I had some misgivings, for if I were to be honest, I must tell of things as they were; and really, this is not my story, but yours" (Milloy, 1999, p. xviii). My call for a different way of doing thingsa changing of the subject, in educational, methodological, and everyday contexts - is, therefore, not new. What is new is that I am interested in what sorts of educational and/or equity-minded frameworks will bring about changes in the structural and interpersonal advantages that accrue to settlers as a result of colonialism. Furthermore, my focus is on what frameworks people can participate in as settlers - allies who want to be proactive - and how these might transform teacher education programs and priorities in Canada.

\section{Interrogating binaries of self/other in equity-focused and Indigenous education}

In Braiding Histories, Dion (2009), a Lenape scholar, asked teacher educators to think seriously about these questions. Learning to confront the unsettling truth about colonization is complicated, in her estimation, because of the refusal "to engage individuals in a specific investigation of their [own] relationship with [Indigenous] peoples" (p. 179). Her concern was with the bifurcation of self/Other that takes place in educational settings, where much of learning is structured by the way in which acquisition of information and attributes "presupposes a distance (or detachment) between the learner and [the] learned" (p. 183). These approaches do little to "support the self-interrogation [that is] necessary to address racism [and colonialism]" (p. 169). In effect, they do little to facilitate any real engagement with social change.

In my current work with teacher candidates at OISE/UT, it is not uncommon to observe what Dion (2009) referred to as "passive empathy," or the tendency to situate oneself as the judging, but inactive, subject. In 2010, the death of Tyler Clementi-the student bullied by classmates at Rutgers University - stirred much class discussion, when candidates took care to state their opposition to homophobic violence, including their commitment to better affirm and understand queer identities. These are important positions to stake out and realize, but how do they help to bring about change in the broader institutional order?

I asked my students to consider themselves differently, and in relation to the bullied other-to consider what it is about heterosexuality (perhaps better stated as sexuality in general) that requires repeated violence and cowardice. My point is that normalcy - in this case heternormativity - needs also to be troubled in classroom contexts. We will only come to know and change heterosexist supremacy if we are able to identify its inner workings as a modality of power that polices our realization of erotic and gendered diversity (Cannon, 1998).

With respect to anti-homophobia education, Schick (2004) explained that even if education about the Other is successful, "the approach cannot avoid rendering complex lives as something to be understood, creating voyeurs of...students and reinforcing a social and intellectual division of 'us' and 'them"' (p. 248). She called for an enabling pedagogy, centered on disrupting the self/Other binary, "to transform the process by which the Other is differentiated from and subordinated to the "norm"' (p. 249). The call for a pedagogy that troubles normalcy is as much relevant in anti-colonial contexts as it is in teaching about homophobia. Addressing colonial dominance must come to mean more than seeking to understand the lives of people who experience it (Srivastava \& Francis, 2006; see also Ellsworth, 1997). 
Schick and St. Denis (2005) explored this set of possibilities and contradictions. The bifurcation of self/Other, they suggested, leads some teachers, students, and faculty to conclude that they are culturally neutral and, therefore, can be a helper to Indigenous peoples in defining their culture (see also Dion, 2009). As they stated:

'The Other' [is frequently] positioned as an exotic spectacle that the dominant culture may appreciate and consume. As students like to say 'I am fascinated by all the cultures'... The onus remains perpetually on Aboriginal teachers and students to explain [and] exhibit the markers by which they can be known as the other. (p. 309)

In short, focusing in on "the Other" does little to help non-Indigenous peoples to know, understand, and challenge their own investment in colonial dominance and self-identification. Therefore, Schick and St. Denis called for a more systematic and far ranging pedagogy aimed at having non-Indigenous peoples think about the construction of the Other, and their own investment in that construction.

I would add the proviso that the objective must not be to dispense entirely with education about the Other. As Kumashiro (2000) noted, focusing on the Other may be important and strategically useful, especially where knowledge is "incomplete because of exclusion, invisibility, and silence, or distorted because of disparagement, denigration and marginalization" (p. 32). Indeed, some measure of reflexivity and self-examination is required to think critically about difference-making, or to provide, as Sefa Dei (2006) described, "a critical perspective that interrogates the nature of asymmetrical power relations, as well as the rationality of the power of dominance in society" (p. 8).

There is likely no one approach to anti-oppressive education that is "correct" and, in fact, many approaches compete with and at times contradict each other. As Kumashiro (2004) acknowledged, "No practice, in and of itself, is anti-oppressive. A practice can be antioppressive in one situation and quite oppressive in another. Or it can be simultaneously oppressive [and] anti-oppressive..." (p. 15). Kumashiro spoke of a reality that should come as no surprise if we have given thoughtful consideration to theories of anti-oppressive education. To build on his insight, no practice is anti-oppressive in and of itself because, for that to be possible, we would need to undermine our everyday lived subjectivity. Every one of us experiences some degree of privilege - think of the institutions in which we teach and learn, and then think about who is absent - and this privilege varies depending on the context and circumstances we find ourselves in. Power, to use the Foucauldian notion, depends on the material, symbolic, discursive, and structural arrangements that surround us in any given moment (Hill Collins, 2003; Razack, 1998).

I concur with Curry-Stevens (2007) that "the privileged need distinct approaches to catalyze their involvement with social justice” (p. 36). If, as Razack (1998) took care to point out, "no one is off the hook since we can all claim to stand as oppressor and oppressed in relation to someone" (p. 47; see also Narayan, 1988), then it is incumbent upon us as educators to find ways to encourage people to engage with their privilege. And, as Hill Collins (2003) wrote, we need to do this on both dominant and subordinate sides. I believe this is key to realizing the strategic frameworks for having all peoples_-not just Indigenous peoples_-participate in an antioppressive pedagogy.

It is noteworthy that much of the literature charting educational, pedagogical, and institutional shortcomings — and this is my major criticism — falls short of addressing the matter 
of reform, specifically the range of possibilities for having non-Indigenous peoples engage with histories of settler colonialism. The reality is that a number of us spend most of our time with privileged learners, many of them white, faced with the challenge of rendering the invisible visible. We have the formidable task of teaching courses concerned with social inequality, racism, colonialism, and Indigenous peoples. We ask individuals to think about where it is that they stand in relation to all of these issues (Cannon \& Sunseri, 2011).

The doing of anti-oppressive pedagogy is time consuming, difficult, and challenging. In the absence of collaborative efforts to engage with the resistance we face-and it is important to chart out and describe this resistance - it is lonely work. It requires great care in linking diverse communities, and providing for a united front against the racism and colonialism aimed at Indigenous peoples in Canada. But the most urgent challenge is in finding common ground. To find where this common ground lies, we need to think seriously about privileged learners. We also need to place developing literature concerned with the building of settler-Indigenous alliances into productive dialogue with educational literatures aimed at building anti-oppressive pedagogy.

\section{Finding/troubling common ground in anti-oppressive pedagogy}

To outline the importance of focusing on privileged learners to disrupt dominant ways of knowing and facilitate change, I turn to a recent interview with Tsalagi scholar Andrea Smith (Khan, Hugill, \& McCreary, 2010). Smith's (2008) publication on working across cultural differences addressed matters of partnerships and alliance building, and is part of an emerging scholarship concerned with "the ethics and strategies of forming coalition politics across political [and religious] divides" (p. 200). This work is relevant to education, relationship building, and restitution for colonial injustice.

In the Khan et al. (2010) interview, Smith spoke of working with privileged learners, and challenges this can pose in classroom and activist-centered contexts. She explained that it is often easier to start from a framework that assumes everyone a potential ally rather than an enemy. In clarifying what this means in practice, she stated:

I find that when I talk about issues of racism...it is easier to talk about capitalism first. When everyone begins to see that they are not part of the five percent, it gives them the investment to start addressing the other privileges [because] addressing issues of class entails their own liberation too. This realization enables everyone to see that the reason they need to deal with racism is not so that they can be nice to people of colour, but so that they can dismantle a larger system that oppresses them too. (p. 42, emphasis mine)

It is important for learners to catalyze their involvement in social justice by considering the impact of oppression - in this case class inequality — on their everyday lives. Before engaging people in questions about white privilege and colonial dominance, it is vital to encourage them to realize their varying exclusions, so that an invested and shared sense of commitment and thinking about action might be realized.

For Smith, the goal is finding common ground to address matters of privilege, and having people acknowledge the need to address privilege collectively, rather than individually (Khan et al., 2010). By having non-Indigenous peoples think about their access to class-based privilege, 
she invites them to envision a collective project to transform oppressive conditions and inequity - a world not characterized by unequal distribution of wealth, but where "everybody has privileges [and] skills [and] the power to make decisions" (p. 43), and where everybody is held accountable. Her praxis is consistent with Hill Collins (2003) who wrote that we are not in a position to realize "new ways of thought and action" until we understand "the multiple systems of oppression that frame our lives" (p. 332). The goal is neither to confess nor feel bad (Khan et al., 2010), but to foster a collective responsibility for our complicity in social inequality, and to work toward changing this.

I seek to employ similar pedagogy in my work with pre-service teachers. Like Smith, I focus on social class, and other forms of privilege as they interact and converge with one another. I am intent on having teacher candidates acknowledge and better understand how and why social and economic hierarchies shape our world, and how no one is free from being an oppressor or being oppressed. With respect to finding common ground, I start my course with a "step exercise" developed by Logan et al. (1991). The goal is to introduce the concept of privilege and oppression and its effects on all individuals, to foster a better sense about the complexity of individual identities, and to make transformative use of developing empathy.

By being assigned a pseudo identity, based on religious, ethnic, colonial, gender, sexual, social class, and ability differences, participants are encouraged to realize that privilege and oppression varies according to context and/or circumstances-mediating our everyday experience of racism, for example. Teacher candidates come to better appreciate the complex nature of privilege and oppression. As one candidate wrote in a 2010 evaluation: "I found the step activity in class to be quite meaningful [in terms of] awareness of issues involving oppression and privilege... I now have a better understanding about how I personally influence change or the status quo."

I have found that participants come to care enough about privilege and the way that it structures our collective being to begin a nine-week intensive conversation about the reflective habits of mind that might be useful in classrooms for addressing it. More importantly, they realize that "there are very few pure victims or oppressors, and that each one of us derives varying amounts of penalty and privilege from the multiple systems of oppression that frame our lives" (Hill Collins, 2003, p. 332). Only after engaging in such realizations are individuals positioned to consider course objectives, including the violence engendered in privileged ways of knowing - through real or perceived whiteness, heterosexuality, Christianity, colonization, class status, and/or physical and mental ability.

In keeping with the focus on finding common ground, I incorporate matters of environmental sustainability into my teaching to illuminate how systems of oppression affect individual lives. Murdocca (2010) examined the ongoing violence of colonialism in Canada through a look at the 2005 water crisis on the Kashechewan Cree Nation reserve. Media reports of the crisis revealed common and difference-making gaps in the knowledge presented and produced about Indigenous peoples in Canada. Steckley (2003) and LaRocque (1993) have written about "social problems" or "victim blaming" approaches used to highlight Indigenous disparities. The reality is that Indigenous peoples tend only to become visible when they fit into a social problems category of analysis. These difference-making practices, as my colleague and I have suggested (Cannon \& Sunseri, 2011), foreclose discussions we need to be having about the history of colonization in Canada, as well as the stake that we all have in sustainability practices.

I invite teacher candidates to see concerns about environmental sustainability as a problem 
we all share. Film and artistic media is useful in making this connection, particularly the film by Annie Leonard entitled The Story of Stuff (2007). This short video explores the excesses of consumerism, connecting environmental and social issues through basic Marxist concepts like production, distribution, consumption, and disposal. Leonard's message that "you cannot run a linear system on a finite planet," calls on viewers to create a just and sustainable world, and establishes Lyons' point that "we are all under the same law of the land, air, water, and spirit" (1989, p. 207).

These are some of many ways we might have privileged learners engage with matters of social inequality. The potential for environmental destruction, to echo Smith (2008), gives people reason — an investment — to start addressing related oppressions, in turn opening a space for conversations about Indigenous peoples, and the historical exploitation of their lands and labour. The connection between consumerism and environmental destruction, including their intimate connections to colonization and capitalism, becomes clear. People begin to realize that the advantages accruing to them from colonialism will afford no relief from environmental devastation.

\section{Looking forward and hearing back from settlers about colonialism}

It is worth asking if the work we do to engage privileged learners results in tangible outcomes, especially where addressing colonial reparations is concerned. While further research is needed to realize efforts to broaden and explore settler investments in anti-oppressive activism and pedagogy, the work of McCreary (2005) is one demonstration of what happens as individuals come to see their connection to histories of colonization, and develop a shared sense of commitment and thinking about actions that might reconcile these historic pasts (see also Freeman, 2000).

McCreary (2005) defined pedagogical strategies employed by the late Patricia Monture (see also Johnson, 2007), who would start her courses by asking those present to define their "treaty rights." McCreary reflected:

Professor Patricia Monture asked us: who here has treaty rights? I did not raise my hand. Neither did any of the other white students.... Professor Monture pointed out that treaty rights ... possessed by whites and other settler nations are different than those possessed by First Nations, but each of us here possesses [them]. (p. 6-7)

As this excerpt suggests, a pedagogy that starts, not with Indigenous peoples, but with settlers, has the possibility of effecting important outcomes. Monture, a Kanienkahaka scholar, was committed to seeing those outcomes realized, and to teaching her students to think about treaty relations. For her Indigenous students, this meant keeping the spirit of nation-to-nation agreements on the minds of young people. For non-Indigenous peoples, it meant realizing themselves as beneficiaries, sometimes for the first time. I am proposing that we continue this type of thinking about where to start in our dialogue. The importance of encouraging nonIndigenous peoples to engage with the question of treaty rights cannot be underestimated.

McCreary (2005) then identified settler responsibilities in Canada, testimony to the effectiveness and importance of Monture's pedagogy. He listed them as including, but certainly not limited to: the right to one's own religion; the right to share land; the right to agricultural and 
economic activities; the right to political self-determination; and the right to peace and goodwill. As he described:

Treaties are foundational agreements that provide a common framework for peaceful coexistence between First Nations and settlers. Some 'treaty abolitionists' argue that treaties grant particular individuals special rights and privileges, creating inequality...But they forget that we are all, in fact, treaty people. Treaties are two-party agreements that bestow rights and obligations upon both parties.... (p. 6, emphasis mine)

Just as McCreary sought to recover the original spirit of relationships upon which Canada was established as a nation, I take the position that, in Canada, and in teacher education, we need to further cultivate and realize these sorts of endeavours.

The approaches I have outlined with respect to changing the dialogue and subject in Indigenous education do not exhaust the range of possibilities that have been realized where having students engage with questions of privilege is concerned. What I have hoped to show is that all of them seek to disrupt the self/Other binary, and to trouble normalcy. The idea of a decolonizing pedagogy aimed at fostering collaborative relationships, in working to find common ground with privileged learners, is entirely consistent with calls coming from literature concerned with apologies and "reconciliation" (see Alfred, 2009). As Mackey (Forthcoming, 2012) suggested, much previous discussion has centered on appeasing Indigenous interests without any real thought given to settler investments.

My colleague and I (Cannon \& Sunseri, 2011) suggested that Indian residential school resolutions cannot take place in Canada in the absence of critical reflection and collective responsibility, nor can reparations for colonialism be made. Canadians cannot simply "feel good about feeling bad," or as Simon (Forthcoming, 2012) eloquently stated:

[T] he act of acknowledging victimhood [cannot be] reduced to an affective transaction in which one both recognizes and 'feels for' the pain of others, [where] there is no need to ask difficult questions that might implicate one's psychic, social and economic investments in the conditions and institutions responsible for the genesis and prolongation of that pain. (para. 9)

In seeking to reconcile colonial pasts, specifically histories of racialization and residential schools, it is necessary for Canadians to relinquish structural advantages acquired through colonialism and privilege. As Simon (Forthcoming, 2012) emphasized, it will be of no use to only focus on Indigenous peoples, but will require "asking non-Aboriginal Canadians to work out where we 'fit in' to Aboriginal history, not just where Aboriginal history fits into the history of Canada" (para. 13).

And so we arrive back at the question of how to encourage privileged learners to take responsibility for histories of settler colonialism. Will it take place through the introduction of Indigenous world-views into teacher education curricula — or, through efforts to "Indigenize" the academy alone (Grande, 2011; St. Denis, 2009)? Will it take place through the employment of "white complicity pedagogy" (Applebaum, 2010)? And, importantly, what does it mean to ask Canadians, especially new Canadians, to take responsibility for colonial injustice?

\section{Working across our differences to engage new Canadians and settlers of colour}


In a public address at the University of Toronto in December 2009, Justice Murray Sinclair raised the intricacies of reconciliation in Canada, his words critical in pointing to the unique challenges involved in calling on new Canadians to take responsibility for colonialism. As he stated:

We have been challenged to determine what...we are going to say to new Canadians who themselves are unable to accept responsibility for anything...because they're not the ones who did this...But what I say to them is this: if you are to properly enjoy the benefits of this society...you have to take responsibility for the fact that what you have now, what you are gaining now, is something...that was taken away improperly.

Pursuing the issues raised by Justice Sinclair needs to be taken seriously. We need to stake out, name, and explore the intellectual and intercultural relationships that exist and might be further realized between settler, diasporic, and Indigenous populations-including the possibilities, challenges, and limitations that surround the building of these alliances in both theory and research. Sinclair raised what I believe to be - and what is still yet to become - one of the single most pressing issues to face us in Canada into the twenty-first century. The truth is that in light of the diversity that makes up Canada there are no easy solutions, and working across our differences will be hard work.

Internationally, Indigenous-diasporic relationship building has received ample, and oftentimes discomforting, attention from Indigenous scholars. I refer here to Trask's (2000) "Settlers of Color and 'Immigrant' Hegemony: 'Locals' in Hawai'i," and Fujikane and Okamura's (2008) Asian Settler Colonialism, which charted the nature of White- and AsianSettler colonialism in the context of Hawaii. In terms of putting forth similar discussions in scholarly and intellectual engagements in Canada, while we may not be as far advanced, it is important to note the contributions of Madden (2009), Lawrence and Dua (2005), and Lawrence and Amadahy (2009). The reality is that these conversations - including the one about the complicity of diaspora in the ongoing colonization of Indigenous peoples-have only started to play themselves out in Canadian scholarly literatures, and with notable gaps, in educational writings.

I had the pleasure of working with 17 OISE/UT graduate students in 2011 to think through some of these issues. To the best of my knowledge, my course "Centering Indigenous-Settler Solidarity in Theory and Research" is the only graduate course at University of Toronto to explore and reflect on building anti-colonial alliances. My motivation stems in part from realizing that I teach in one of the most diverse graduate programs in the country, but also from the realization that I can no longer avoid the necessity of building intercultural relationships when the very core of my emotional, spiritual, and physical being - as both Haudenosaunee and White-embodies these very alliances.

I am not alone in my efforts. Haig-Brown (2009) directly addressed the matter of building diasporic-Indigenous relationships. She charted a pedagogical set of interventions aimed at creating dialogue, including the use of a "decolonizing autobiography" (p. 12-15) that invited students to locate themselves in relation to the question: whose traditional land are you on? She described the importance of having students come to the realization that they do not only stand in 
relation to white peoples in Canada, but also in relation to Indigenous peoples and their lands. These are important issues to formulate both in and through our classrooms and pedagogy.

Dion (2009) also outlined a strategy for engaging diaspora in anti-colonial dialogue. She proposed a "critical pedagogy of remembrance" aimed at combating the "perfect stranger" phenomenon (p. 179) — the tendency to claim little or no knowledge about Indigenous peoples. As Dion pointed out, for diasporic populations in particular, disrupting the binary of self and Other can create unique opportunities as people engage with difference and the non-singularity of oppression. These were realized by a woman of colour who recognized that her own experience of colonialism was different than that of Indigenous peoples in Canada (p. 188). It is only in coming to understand these differences between us as colonized peoples that we might hope to lodge successful resistance against colonialism.

The work of Dion and Haig-Brown does not exhaust the theoretical range of educational literatures that address ways of engaging diasporic populations in thinking about Indigenous peoples and the history of settler colonialism. Nor do these authors speak to the emotional and psychic complexities this can and often does present. What I have sought to do in identifying them is to suggest the need for further research and work in this area. Educational, classroombased, and pedagogical literatures need to think about having non-Indigenous peoples, especially those who are new Canadians, locate and name their investment in colonial dominance, including how best to engage with questions of reform and restitution (Alfred, 2009; Day, 2010).

\section{Charting a new path: Difference, diaspora, and Indigenous transnationalism}

Who is a settler? Who is Indigenous? Where do those who identify themselves as Indigenous peoples fit in - notably, those who arrive at Turtle Island from colonized countries, fleeing from oppression and often violence? The latter raises many significant issues only tangentially explored in Canada by scholars of racism, nationalism, and settler colonialism (Lawrence \& Dua, 2005; Mawani, 2009; Phung, 2011; Sharma \& Wright, 2008/09; Simpson et al., 2011; Thobani, 2007).

It is vital to pay attention to and build upon this emerging scholarship. We need to ask how we are engaged with, and indeed engaging, diverse peoples — in particular migrant Indigenous populations - in thinking about and challenging histories of racism, colonialism, and dispossession. How do we imagine and understand the relations between us as Indigenous peoples, both at home and globally? And, how do we envision relations between us in terms of citizenship, identity, belonging, and solidarity?

In Canada, it is unmistakable that even migrant Indigenous peoples are implicated - at least structurally speaking, and in terms of the nation-state - in the ongoing dispossession of our lands and nations (Lawrence \& Amadahy, 2009; Lawrence \& Dua, 2005). Much of this stems from institutionalized practices of citizenship that are premised on legacies of colonial power and white supremacy (Sefa Dei, 2011). Thobani (2007) observed how historically, and even today:

The extension of citizenship rights to ... immigrants [has] resulted in their qualified integration into the political community [and] at the cost of fostering their complicity in the colonial domination of Aboriginal peoples. (p. 76)

As official state-based policy, multiculturalism works to further colonial injustice. Indeed, "Canadian citizenship remains predicated upon the erasure of Aboriginal sovereignty" and will 
remain as such unless it "can be transformed in relation to the realization of Aboriginal sovereignty" (ibid., p. 250). Citizenship is also fashioned in a way that structures and transforms the relations that exist and are possible between us as Indigenous peoples. As Thobani explained, this "compels us to negotiate and comprehend our identities on narrow grounds, discouraging and possibly foreclosing the possibility of alliances that might allow a systemic challenge to white dominance [and] patriarchy" (ibid., p. 175).

Lawrence and Amadahy (2009) made a similar point with respect to citizenship in relation to Black-Indigenous relations. They suggested, "black people without known Indigenous heritage... may have little allegiance to the Canadian settler state but have no option for their survival but to fight for increasing power within it" (p. 126; see also Madden, 2009). The literature reveals how difficult it is to realize citizenship outside of state-based terms. Yet it speaks to the promise of realizing a new set of possibilities - albeit yet to be articulated and with notable structural difficulties to overcome - where the realization of citizenship and a new set of relationships is concerned. Indigenous scholars in North America have been considering this matter for many years.

Smith $(2005 ; 2008)$ discussed a relational vision of sovereignty emerging in what she referred to as "native feminism." In her estimation, it is common for Indigenous scholars, some adopting the label "feminist," to refute state-based versions of sovereignty, and by extension, the structural limitations of Canadian citizenship (see also D'Arcangelis, 2010). The work of Monture (1999) is exemplary in this regard. As she wrote:

Sovereignty (or self-determination)... is not about 'ownership' of territory...We have a Mohawk word that better describes what we mean by sovereignty and that word is tewathata:wi. It best translates into 'we carry ourselves'...What sovereignty is to me is...the responsibility to carry ourselves collectively as nations, as clans, as families...as [Mohawk citizens]... What must be understood then is that the...request to have our sovereignty respected is really a request to be responsible. I do not know of anywhere else in history where a group of people has had to fight so hard just to be responsible. (p. 36, emphasis mine)

Monture insisted on realizing our agency as sovereign citizens outside of state-based taxonomies. However difficult this might be in light of colonial dominance and existing structural imperatives, it is both urgent and necessary. Schools in particular need to work at contemplating and realizing a way to inspire migrant Indigenous populations pedagogically, and in classrooms, to think differently about citizenship and to realize a new set of relationships. The work of Monture and others is significant also because it invites a sustained dialogue about how we relate to each other as Indigenous peoples and nations. As Smith (2008) wrote, sovereignty is, and must be, "articulated as an open concept that suggests that a nation cannot be completely insular but must position itself in a good way with the rest of the world," adding that "it is interesting... how often non-Indians presume that if Native people regained their land bases they would necessarily call for the expulsion of non-Indians from them" (p. 262).

The preference to think of our agency as sovereign citizens, outside of propertied notions of territory and occupied space, and in relational terms, is being addressed by diasporic Canadians (see Mathur et al., 2011). Migrant Indigenous peoples have started to engage with the idea in literature (see Altamirano-Jiménez, 2008; Adefarakan, 2011), addressing explicitly the 
matter of acknowledging, relating to, and seeking to transform the experience of living as colonized peoples on colonized lands. Declaring her own investment, and sense of responsibility as a diasporic Canadian, "settler," and Yoruba woman, Adefarakan (2011) spoke of migrant Indigeneity, rejecting definitions of Indigeneity as sometimes co-opted by white settlers and their descendants that "anchor romantic amnesiac constructions of themselves as benevolent founders of Canada as a nation" (p. 40; see also Tuhiwai Smith, 1999). In charting a new path, Adefarakan underscored the need to give "serious attention...to the multiple and diverse experiences that Indigenous peoples have under imperialism and colonialism" (p. 39). Sefa Dei (2011) foregrounded similar thinking that Indigeneity be better theorized through "dialectical histories of materialism" and suggested the need "to understand holistically the limitations, possibilities, consequences, and the implications... of what constitutes settler, of the question of immigration, of how we come to experience/understand belonging" (p. 25). We need to "make sense of the colonial, [and] questions of identity...through the contemporary edict of Western globalization" (ibid.).

My point in drawing attention to this scholarship is not only to suggest that much needs to be done where the building of intercultural relationships between Indigenous peoples is concerned, but also to acknowledge that much is being done already to build and foster such dialogue. To further this scholarship, teacher education programs and educators must find new ways of engaging Indigenous peoples (see Altamirano-Jiminéz, 2008). This process will undoubtedly reveal insights about the resilience of colonized peoples, the nature of colonial subjectivity, and perhaps more importantly an invigorated way of thinking about citizenship. These sorts of transformations and thinking are imperative in Canada (Thobani 2007). But before any real or significant change is possible with respect to citizenship, we will need to "position indigenous people's struggles," as Wong (2008) stated, "instead of normalized whiteness [being] the reference point through which we come to articulate our subjectivities" (p. 158).

Of course, we cannot blindly forget structural considerations. The power of colonialism to position Indigenous bodies in different and sometimes hierarchical ways will continue to complicate relationships. We need to find ways of understanding how these complex vagaries of racist and colonial power come to manipulate, and indeed (in)voluntarily implicate us in one another's oppressions. As Mawani (2009) documented, finding how to think pedagogically about the "variegated forms, patterns, and rhythms that underpin colonial encounters" (p. 7) is also a component of moving forward. We need further thoughtful analyses through a lens of anti-oppressive theory.

It is necessary to understand that every one of us experiences some degree of privilege. This is true even for Indigenous peoples in what is being called North America. As Smith (2008) has pointed out, United Nations political participation is afforded by our ability to travel to either Geneva or New York with greater ease then Indigenous peoples in other parts of the world. This reminder is not intended to absolve individuals from taking responsibility for ongoing settler colonialism, or to suggest that the dispossession of lands in Canada is not taking place. It is, rather, to point out that relations of power are complex and continue to shape our decolonization and activism.

It will be counterproductive to think in solely hierarchical terms about oppressions when creating dialogue and sorting through the processes of structure, agency, and power. Before it is possible to foster a collective responsibility for our complicity in social inequality, we need to think differently about privilege and oppression, seeing the myriad of ways in which we are at 
once invested. Oppression is both a shared experience and something that is experienced differently. As Sefa Dei and Asgharzadeh (2001) stated:

Oppression should be looked at as a site encompassing varieties of differences, categories, and identities that differentiate individuals and communities from one another and at the same time connect them together through the experience of being oppressed, marginalized, and colonized. (p. 316)

How is education and academic scholarship bringing us closer to, or facilitating, these sorts of understandings? How is it placing the minds and voices of migrant Indigenous and Indigenous peoples in a diverse Canada together into new and productive dialogue? If, as HaigBrown (2009) noted, students must come to realize that they not only stand in relation to white peoples in Canada, but also in relation to Indigenous peoples and their lands, then the same must hold true for migrant Indigenous populations. Teacher education must seek to nurture, promote, and more actively understand the kinds of alliances that exist - and are yet to be built - between Indigenous peoples in Canada and migrant Indigenous peoples. We need to chart the relationships that exist, could potentially exist, and have yet to be established between us in educational, pedagogical, and curricular contexts.

But these are not the only things needed to build bridges. We need to create spaces, symposia, colloquia, and classrooms for exploring and developing critical connections, transformative pedagogies, and collaborations in both research and in practice. These hold great promise in working together across our differences and complicity, and better understanding settler, diasporic, and Indigenous nations. It is in these very spaces that we will begin to chart out a new set of possibilities - and collaborations - aimed at the building of alliances, and at the rejuvenation of our historic, treaty-based, and nation-to-nation partnerships.

\section{Conclusion}

It seems appropriate to conclude by asking: what does it mean to be an ally of Indigenous education? I want to re-state here that it starts, not in thinking about colonialism as an exclusively Indigenous problem or struggle, but rather, in recognizing that every non-Indigenous person has a stake in colonial dominance and reparations. It starts by thinking about, and working to disrupt, the binary of self/Other that keeps us from acknowledging our differences and connections, making us incapable of facilitating any real change or restitution for colonial grievances. Change must start by troubling, and teaching others to trouble, the interpersonal and institutional normalcy of things - the tendency to not name, know, or otherwise mark settler privilege.

In broader institutional terms, change means more than the mere incorporation of Indigenous culture and world-views into teacher education programs and other curricula. It also requires that we give thought to racism and working together across our differences, especially where diasporic, migrant Indigenous, and new Canadians are concerned. The challenge we face as students, activists, and educators might best be considered as much a problem of history as it is of the present. In combating settler colonialism, we must challenge what we think we know about Indigenous peoples. Change takes place when we seek these kinds of self-(and Other-) interrogations. 


\section{References}

Adefarakan, T. (2011). (Re)Conceptualizing "indigenous" from anti-colonial and black feminist theoretical perspectives: Living and imagining indigeneity differently. In G. J. Sefa Dei (Ed.), Indigenous philosophies and critical education: A reader (pp. 34-52). New York: Peter Lang Publishing Inc.

Alfred, T. (2010). What is radical imagination?: Indigenous struggles in Canada. Affinities: A Journal of Radical Theory, Culture, and Action, 4(2), 5-8.

Alfred, T. (2009). Restitution is the real pathway to justice for indigenous peoples. In Aboriginal Healing Foundation Research Series, Response, responsibility, and renewal: Canada's truth and reconciliation journey (pp.178-187). Ottawa: Aboriginal Healing Foundation.

Altamirano-Jiménez, I. (2008). The colonization and decolonization of indigenous diversity. In L. Simpson (Ed.), Lighting the eighth fire: The liberation, resurgence, and protection of indigenous nations (pp.175-186). Manitoba: Arbeiter Ring Publishing.

Applebaum, B. (2010). Being white, being good: White complicity, white moral responsibility, and social justice pedagogy. Lanham, Maryland: Lexington Books.

Cannon, M. J. (1998). The regulation of first nations sexuality. The Canadian Journal of Native Studies, 18(1), 1-18.

Cannon, M. J., \& Sunseri, L. (Eds.) (2011). Racism, colonialism, and indigeneity in Canada: A reader. Toronto: Oxford University Press.

Curry-Stevens, A. (2007). New forms of transformative education: Pedagogy for the Privileged. Journal of Transformative Education, 5(1), 33-58.

D'Arcangelis, C. (2010). Exploring indigenous feminist relational sovereignty: Feminist conversations, non-colonizing solidarities, inclusive nations. Atlantis: A Women's Studies Journal, 34(2), 127-138.

Day, R. J. F. (2010). Angry Indians, settler guilt, and the challenge of decolonization and resurgence. In L. Simpson \& K. L. Ladner (Eds.), This is an honour song: Twenty years since the blockades (pp. 261-269). Winnipeg: Arbeiter Ring Publishing.

Davis, L. (2010). Alliances: Relenvisioning indigenous-non-indigenous relationships. Toronto: University of Toronto Press.

Dion, S. D. (2009). Braiding histories: Learning from Aboriginal peoples' experiences and perspectives. Vancouver: University of British Columbia Press.

Ellsworth, E. (1997). Teaching positions: Difference, pedagogy and the power of address. New York: Teachers College Press.

Freeman, V. (2000). Distant relations: How my ancestors colonized North America. Toronto: McClelland and Stewart.

Fujikane, C., \& Okamura, J. Y. (Eds.) (2008). Asian settler colonialism: From local governance to the habits of everyday life in Hawai' $i$. Honolulu: University of Hawai'i Press.

Government of Canada. (2010). Proceedings of the Standing Senate Committee on Aboriginal Peoples. Issue \#10 (September). Ottawa: Senate of Canada.

Grande, S. (2011). Confessions of a full-time Indian. Journal of Curriculum and Pedagogy, 8(1), 40-43.

Haig-Brown, C. (2009). Decolonizing diaspora: Whose traditional land are we on? Cultural and Pedagogical Inquiry, 1(1), 4-21. 
Hill Collins, P. (2003). Toward a new vision: Race, class, and gender as categories of analysis and connection. In M. S. Kimmel \& A. L. Ferber (Eds.), Privilege: A reader (pp. 331-348). Colorado: Westview Press.

hooks, b. (1988). Talking back: Thinking feminist, thinking black. New York: South End Press. Johnson, H. (2007). Two families: Treaties and government. Saskatoon: Purich Publishing. Khan, S., Hugill, D., \& McCreary, T. (2010). Building unlikely alliances: An interview with Andrea Smith. Upping the Anti: A Journal of Theory and Action, 10, 41-52.

Kumashiro, K. K. (2004). Against common sense: Teaching and learning toward social justice. New York: Routledge.

Kumashiro, K. K. (2000). Toward a theory of anti-oppressive education. Review of Educational Research, 70(1), 25-53.

LaRocque, E. (1993). Three conventional approaches to native people in society and in literature. In B. Balon \& P. Resch (Eds.), Survival of the imagination: The Mary Donaldson Memorial Lectures. Regina, SK: Coteau Books.

Lawrence, B., \& Amadahy, Z. (2009). Indigenous peoples and black people in Canada: Settlers or allies? In Arlo Kempf (Ed.), Breaching the colonial contract (pp. 105-136). Netherlands: Springer.

Lawrence, B., \& Dua, E. (2005). Decolonizing anti-racism. Social Justice, 32(4), 120-143.

Logan, J., Kershaw, S., Karban, K., Mills, S., Trotter, J., \& Sinclair, M. (1991). Confronting prejudice: Lesbian and gay issues in social work education. England: Ashgate Publishing Ltd.

Lyons, O. (Jo ag quis ho) (1989). Power of the good mind. In J. Bruchac (Ed.), New voices from the longhouse: An anthology of contemporary Iroquois writing (pp. 199-208). New York: The Greenfield Review Press.

Mackey, E. (Forthcoming, 2012). The apologizers apology. In P. Wakeham \& J. Henderson (Eds.), Reconciling Canada: Historical injustices and the contemporary culture of redress. Toronto: University of Toronto Press.

Madden, P. (2009). African Nova-Scotian Mi'kmaw relations. Halifax: Fernwood Publishing. Mathur, A., Dewar J., \& DeGagne, M. (2011). Cultivating Canada: Reconciliation through the lens of cultural diversity. Ottawa: Aboriginal Healing Foundation.

Mawani, R. (2009). Colonial proximities: Crossracial encounters and juridical truths in British Columbia, 1871-1921. Vancouver: University of British Columbia Press.

McCreary, T. (2005). Settler treaty rights. Briarpatch, 34(5), 6-9.

Miles, T. \& Holland, S. P. (2006). Crossing waters, crossing worlds: The African diaspora in indian country. Durham: Duke University Press.

Milloy, J. (1999). A national crime: The Canadian government and the residential school system, 1879-1986. Winnipeg: University of Manitoba Press.

Monture, P. (1999). Journeying forward: Dreaming First Nations' independence. Halifax: Fernwood Publishing.

Morgensen, S. L. (2011). Spaces between us: Queer settler colonialism and indigenous decolonization. Minneapolis: University of Minnesota Press.

Murdocca, C. (2010). 'There is Something in that Water': Race, Nationalism and Legal Violence. Law and Social Inquiry, 35(2), 369-402.

Narayan, U. (1988). Working together across difference: Some considerations on emotions and political practice. Hypatia, 3(2), 31-48 
Phung, M. (2011). Are peoples of colour settlers too? In A. Mathur, J. Dewar \& M. DeGagné (Eds.), Cultivating Canada: Reconciliation through the lens of cultural diversity (pp. 291298). Ottawa: Aboriginal Healing Foundation.

Porter, R. B. (1999). The demise of the Ongwehoweh and the rise of the Native Americans: Redressing the genocidal act of forcing American citizenship upon indigenous peoples. Harvard Black Letter Law Journal, 15, 107-83.

Razack, S. H. (1998). Looking white people in the eye: Gender, race, and culture in courtrooms and classrooms. Toronto: University of Toronto Press.

Regan, P. (2010). Unsettling the settler within: Indian residential schools, truth telling, and reconciliation in Canada. Vancouver: University of British Columbia Press.

Schick, C. (2004). Disrupting binaries of self and other: Anti- homophobic pedagogies for student teachers. In J. McNinch \& M. Cronin (Eds.), I could not speak my heart: Education and social justice for gay and lesbian youth (pp. 243-254). Regina: Canadian Plains Research Centre.

Schick, C., \& St. Denis, V. (2005). Troubling national discourses in anti-racist curricular planning. Canadian Journal of Education, 28(3), 295-317.

Sefa Dei, G. J. (2011). Revisiting the question of the "indigenous". In G. J. Sefa Dei (Ed.), Indigenous philosophies and critical education: A reader (pp. 21-33). New York: Peter Lang Publishing Inc.

Sefa Dei, G. J. (2006). Introduction: Mapping the terrain - towards a new politics of resistance. In G. J. Sefa Dei \& A. Kempf (Eds.), Anti-colonialism and education: The politics of resistance (pp. 1-23). Boston, MA: Sense Publishers.

Sefa Dei, G. J. \& Asgharzadeh, A. (2001). The power of social theory: Towards an anti-colonial discursive framework. Journal of Educational Thought, 35(3), 297-323.

Sharma, N., \& Wright, C. (2008/09). Decolonizing resistance, challenging colonial states. Social Justice, 35(3), 120-139.

Simon, R. I. (Forthcoming, 2012). Towards a hopeful practice of worrying: The problematics of listening and the educative responsibilities of the IRSTRC. In P. Wakeham \& J. Henderson (Eds.), Reconciling Canada: Historical injustices and the contemporary culture of redress. Toronto: University of Toronto Press.

Simpson, J. S., James, C. E., \& Mack, J. (2011). Multiculturalism, colonialism, and racialization: Conceptual starting points. The Review of Education, Pedagogy, and Critical Studies, 33, 285-305.

Smith, A. (2008). Native Americans and the Christian right: The gendered politics of unlikely alliances. Durham, NC: Duke University Press.

Smith, A. (2005). Native American feminism, sovereignty, social change. Feminist Studies, 31(1), 116-132.

Srivastava, S, \& Francis, M. (2006). The problem of "authentic experience": Storytelling in antiracist and anti-homophobic education. Critical Sociology, 32(2-3), 275-307.

St. Denis, V. (2009). Rethinking culture theory in Aboriginal education. In C. Levine-Rasky (Ed.), Canadian perspectives on the sociology of education (pp. 163-182). Toronto: Oxford University Press.

St. Denis, V. \& Schick, C. (2003). What makes anti-racist pedagogy in teacher education difficult?: Three popular ideological assumptions. The Alberta Journal of Educational Research, 49(1), 55-69. 
Steckley, J. (2003). Aboriginal voices and the politics of representation in Canadian introductory Sociology textbooks. Toronto: Canadian Scholars Press.

The Story of Stuff Project (2007). The story of stuff. Retrieved from http://www.storyofstuff.com.

Thobani, S. (2007). Exalted subjects: Studies in the making of race and nation in Canada. Toronto: University of Toronto Press.

Trask, H. K. (2000). Settlers of color and "immigrant" hegemony: "Locals" in Hawai'i. Amerasia Journal, 26(2), 1-24.

Tuhiwai Smith, L. (1999). Decolonizing methodologies: Research and indigenous peoples. New York: St. Martin's Press.

Unsettling Minnesota Collective. (2009). Unsettling ourselves: Reflections and resources for deconstructing colonial mentality. Retrieved from http://unsettlingminnesota.org

Wong, R. (2008). Decolonization: Reading Asian and First Nations relations in literature. Canadian Literature, 199, 158-180. 